https://doi.org/10.31470/2706-7904-2021-16-44-48

\title{
МОВЛЕННЕВА КОМПЕТЕНТНІСТЬ ЯК КЛЮЧОВИЙ ЕЛЕМЕНТ ПРОФЕСІЙНОЇ КОМПЕТЕНТНОСТІ МЕНЕДЖЕРА
}

Speech Competence as a Key Element of Manager's Professional Competence

\author{
Olena Vlasenko \\ Ph.D., Associate Professor \\ Hryhorii Skovoroda University in Pereiaslav (Ukraine) \\ interesmore@i.ua \\ https://orcid.org/0000-0002-1011-1965
}

\begin{abstract}
Training specialists in the field of "management" requires them to master professional competence. Analysis of professional competence essence allowed us to identify three main approaches for understanding. Speech is the key element of professional competence. The level of speech competence determines the level of quality the manager's duties performance.
\end{abstract}

Key words: speech competence; professional activity of the manager; professional competence.

\section{Ветуп \\ Introduction}

Перебудова структури освітнього процесу України потребує новітніх підходів до організації та результатів навчання. Розвиток мовленнєвої компетентності стало одним із напрямів, який людина повинна розвивати протягом усього життя. Підготовка фахівців з напрямку «менеджмент» потребує забезпечення їх професійної компетентності. Ключовим елементом професійної компетентності $є$ мовленнєва. Необхідність розуміння ролі мовленнєвої компетентності в процесі професійної діяльності менеджера обумовили вибір теми дослідження.

Мета дослідження - дослідити вплив мовленнєвої компетентності на становлення професійної компетентності менеджерів. 


\section{Методи та методики дослідження Methods and Techniques of the Research}

За допомогою теоретичних та емпіричних методів аналізу і синтезу, індукції і дедукції було проведено аналіз становлення професійної компетентності менеджерів та значення мовленнєвої компетенції в процесі ії опанування.

\section{Результати}

Results

Під упливом мінливого навколишнього середовища кожній людині необхідна низка навичок та компетентностей, які вона буде розвивати на протязі всього життя. Однією з таких компетенцій є мовленнєва. Для реалізації цього підходу в Свропі були прийняті Рекомендації про ключові компетенції для безперервного навчання. Згідно цієї програми, мовленнєва компетентність визначає здатність правильно і ефективно використовувати різні мови для спілкування. (Council Recommendation on Key competences for Lifelong Learning, 2018)

Вважаємо, що дана компетентність повинна охоплювати більший діапазон вмінь, тому більш вподобаним є визначення, мовленнєва компетентність - це володіння вербалізацією, відповідними мовними засобами, ментального змісту думки, яку прагнуть висловити та можливість сприйняття інформації, що представлена доречними мовними засобами.

Аналіз підходів до визначення професійної компетентності дозволив відокремити три основні напрямки ставлення до розуміння сутності професійної компетентності:

Знаннєвий nidxid. Це сприйняття є найбільш традиційним та узагальненим. Воно спирається на визнання компетентності як рівня професійних знань, як поглибленого знання предмета та у результаті - засвоєного вміння. У межах знаннєвого підходу професійна компетентність може бути лише теоретичним потенціалом, або критерієм успішності виконання стандартизованих практичних завдань.

Професіографічний niдxid - полягає у тому, що професійна компетентність представляється у формі еталонної моделі, кваліфікаційної характеристики та визначається відповідно до державного стандарту. Вона окреслює коло спеціальних знань, умінь та навичок, що є адекватними вимогам професії.

Акмеологічний підхід розглядає професійну компетентність як рівень професійно-особистісного розвитку, досягнення високого рівня професіоналізму у конкретних галузях діяльності. Основними напрямками цього підходу є орієнтація на 
вдосконалення професійних вмінь та навичок на всіх етапах життя i діяльності людини, на всебічний розвиток свідомості особистості, як фахівця.

Компетентнісний niдxid у формуванні процесу вищої освіті в Україні став основним. Цей підхід відображає професіографічне ставлення до сутності професійної компетентності в освіті. Компетентності виступають як міра здатності людини забезпечувати професійні навички. Вони мають високий ступінь універсальності та включають широкий практичний контекст. Відповідно формування сукупності професійних компетентностей менеджерів у закладах вищої освіти України проходить декілька етапів (рис.1).

\section{Рис.1}

Процес формування профресійної компетентності менеджерів у ЗВО в Україні

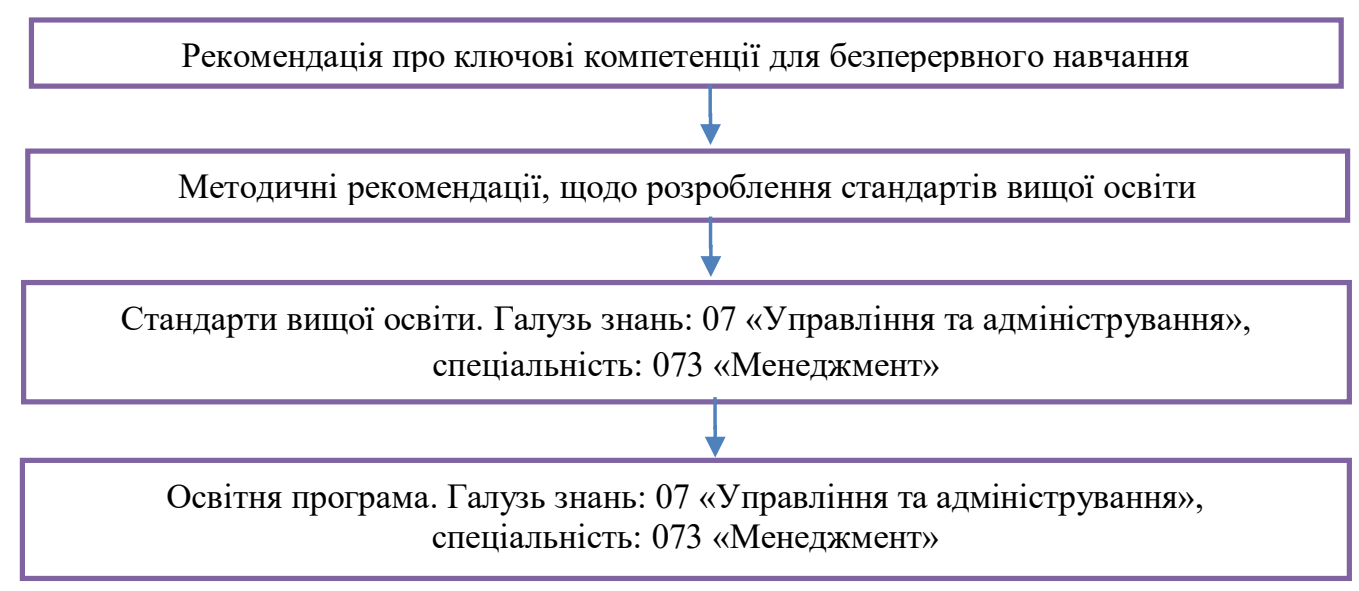

Мовленнєва компетентність є однією із суттєвих частин професійної компетентності менеджера. Вона $є$ одним із основних факторів формування позитивного іміджу будь-якого професіонала. Ця компетентність сприяє успішній самопрезентації більшості фахівців, підвищенню їх ділової активності, ефективності вирішення професійних завдань у сфері комунікацій. Однак для менеджерів, рівень мовленнєвої компетентності визначає рівень якості виконання ними посадових обов’язків.

Відомо, що менеджер - це найманий працівник організації, основним завданням якого є управління іншими співробітниками та ключовими ресурсами. Він забезпечує роботу внутрішньоструктурної діяльності підприємства, налагоджує зв’язки із партнерами, клієнтами. Всі ці функції потребують високого рівня мовленнєвої підготовки.

Аналізуючи вимоги до спеціальності - менеджеру з туризму, можна відмітити, що в індустрії гостинності на сучасному етапі все більшого значення набувають такі якості особистості, як вміння вести діалог і співпрацювати з партнерами та клієнтами, 
забезпечуючи найбільшу ефективність та рентабельність туристичної структури. Саме ці вміння підтримує мовленнєва компетентність.

Проводячи аналіз критеріїв фахівця 3 менеджменту персоналу, можна відокремити вимоги до здатності сприймати, засвоювати та використовувати усну та письмову інформацію. Відповідно, саме такі вміння забезпечує мовленнєва компетентність.

Менеджер, як керівник підлеглих, повинен таким чином викласти зміст завдання, який буде зрозумілий усіма, хто є учасниками проекту. Крім того, він повинен розробляти медіа-план та планувати PR-компанію організації. При цьому керівник повинен вміти делегувати повноваження та розподіляти-відповідальність між усіма учасниками процесу, вміючи донести цю інформацію до робітників. Менеджер повинен бути професіонально грамотним не лише у галузі економіки, а i мови. За все це, також відповідає мовленнєва компетентність.

У своїй професійній діяльності менеджер повинен виконувати такі ролі (Чайка, 2005):

- керівника (при наявності повноважень);

- лідера (при наявності лідерських якостей);

- дипломата (при необхідності вирішувати внутрішні і зовнішні конфлікти);

- вихователя (при необхідності згуртовувати людей);

- інноватора (при необхідності зробити оцінку інновацій та впровадити їх у життя);

- еталон для підлеглих.

При цьому, за останніми дослідженнями (Porter \& Nohria, 2018), кожен керівник має в середньому 37 зустрічей на тиждень, що займає 72\% робочого часу. Найчастіше ідеться про зустрічі з підлеглими віч-на-віч. На другому місці - наради, на яких присутні від 2 до 5 осіб.

Усі ці ролі та функції менеджера обумовлюють опанування професійних вмінь та потребують засвоєння мовленнєвої компетенції.

\section{Висновки Conclusions}

Аналіз підходів до сутності професійної компетентності дозволив визначити, що можна відокремити три основні напрямки розгляду цієї компетентності: знаннєвий, професіографічний та акмеологічний підхід. Мовленнєва компетентність $є$ однією із суттєвих частин професійної компетентності менеджера. Рівень мовленнєвої компетентності визначає рівень якості виконання керівником своїх 
посадових обов'язків. Висвітлені ролі та функції менеджера потребують засвоєння мовленнєвої компетенції.

\section{Література References}

Чайка, Г.Л (2005). Культура ділового спілкування менеджера. Київ: Знання. ANNEX to the Proposal for a Council Recommendation on Key Competences for Lifelong Learning (2018). Retrieved from: https://inlnk.ru/ELzKk

Porter, M.E., \& Nohria, Nitin (2018). How CEOs Manage Time. Retrieved from: https://hbr.org/2018/07/how-ceos-manage-time\#how-ceos-manage-time 